\title{
WPŁYW BRAKU WIEDZY I INFORMACJI NA TURYSTYKE OSÓB NIEPEŁNOSPRAWNYCH Z DYSFUNKCJĄ RUCHU
}

\author{
Julia Szlenk \\ Politechnika Częstochowska \\ Wydział Zarządzania
}

\begin{abstract}
Streszczenie: Obecnie przemysł turystyczny jest jednym z najbardziej dynamicznie rozwijających się sektorów gospodarki światowej. Z roku na rok rośnie liczba turystów, a podróże turystyczne traktowane są jako jeden z ważnych składników życia ludzi. Jednakże pomimo trwającego wciąż rozwoju turystyka osób niepełnosprawnych jest zjawiskiem rzadkim. Wynika to przede wszystkim z braku wiedzy na temat rynku turystów ze specjalnymi potrzebami, marketingu, dostosowania infrastruktury przestrzeni i zarządzania przedsiębiorstwami turystycznymi w oparciu o dialog $\mathrm{z}$ klientem niepełnosprawnym. Artykuł zawiera przykłady innowacyjnych projektów na rzecz rozwoju turystyki osób niepełnosprawnych, przybliża pojęcie niepełnosprawności oraz zawiera analizę i wyniki własnych badań na temat aktywności turystycznej osób niepełnosprawnych mobilnie.
\end{abstract}

Słowa kluczowe: turystyka osób niepełnosprawnych ruchowo, usługi turystyczne, turystyka, innowacje, gospodarka turystyczna oparta na wiedzy, zarządzanie, marketing

DOI: $10.17512 /$ znpcz.2016.2.11

\section{Wprowadzenie}

Coraz więcej osób niepełnosprawnych ruchowo odczuwa potrzebę podróżowania, zwiedzania czy w ogóle wyjścia z domu. Sama chęć uczestniczenia tych osób w życiu społecznym, a więc również w turystyce, jednak nie wystarczy. We współczesnym społeczeństwie osoby niepełnosprawne ruchowo poza turystyką zdrowotną i pielgrzymkową pragną uprawiać innego typu turystykę, na przykład kulturową, krajoznawczą. Większość z nich nie wie, gdzie mogłaby się udać, aby godnie spędzić wolny czas. Mają kłopoty z wyborem organizatora wyjazdów turystycznych. Jest to spowodowane stosunkowo słabo rozpowszechnioną informacją dostarczaną przez branżę turystyczną, a w tym przez biura podróży.

Wiadomo, że turystyka to najprzyjemniejsza metoda rehabilitacji tych osób. Pozwala nie tylko redukować braki ruchowe, ale również rekompensować uczucie mniejszej wartości. Najważniejszym celem uprawiania turystyki przez osoby z dysfunkcją ruchu jest integracja ze społeczeństwem i podtrzymywanie kontaktów społecznych. Uprawiając turystykę, niepełnosprawni podejmują trud pokonywania własnych słabości psychicznych i fizycznych oraz wyznaczania sobie coraz trudniejszych celów. Turystyka jest dla tych osób szkołą przetrwania, w której następuje próba charakteru i determinacji. 
Osoby niepełnosprawne ruchowo to turyści, którzy podczas imprez turystycznych napotykają na wiele barier, takich jak: transport, zakwaterowanie, atrakcje turystyczne, niedostosowane miejsca czy też wspomniane wcześniej bariery informacyjne, na przykład brak informacji o potrzebach i obsłudze tych ludzi, co wynika często ze słabego wyszkolenia personelu branży turystycznej (Kaganek 2009, s. 3-304).

Poziom wymogów dostępności danej usługi turystycznej wzrasta wraz ze stopniem niepełnosprawności ruchowej i dlatego osoby te zauważają malejący poziom jakości świadczonej usługi turystycznej przez organizatorów wyjazdów turystycznych oraz liczbę dostosowanych do ich niepełnosprawności usług turystycznych. Brak informacji to jedna $\mathrm{z}$ głównych przyczyn, które powstrzymują niepełnosprawnych ruchowo przed wybraniem się w podróż (Skalska 2010, s. 19-21).

Osoby niepełnosprawne z dysfunkcją ruchu mają znacznie ograniczony udział $\mathrm{w}$ turystyce, chociaż przysługuje im prawo uczestniczenia w niej na równi ze społeczeństwem zdrowym.

Po wejściu Polski do Unii Europejskiej zmienia się pogląd społeczeństwa na potrzeby osób niepełnosprawnych ruchowo, co powoduje wdrażanie nowych innowacji do turystyki osób niepełnosprawnych, które poprawiają konkurencyjność ofert dostosowanych do wymogów tych osób na rynku turystycznym. Wówczas osoby niepełnosprawne ruchowo staną się najważniejszą częścią oferty biura podróży i będą jej współtwórcami. W Unii Europejskiej rozpoczęto wiele programów wspierających równouprawnienie $\mathrm{w}$ podróżowaniu przez osoby niepełnosprawne ruchowo (Januszewska, Nawrocka 2010, s. 35-48). Spotkały się one z dużym poparciem całego społeczeństwa i do dziś są kontynuowane (Grabowski 2008, s. 61).

Celem artykułu jest próba ukazania wpływu braku wiedzy i odpowiedniej informacji na temat turystyki osób niepełnosprawnych ruchowo oraz zaprezentowanie dobrych praktyk wraz z podjętymi już projektami i przedsięwzięciami opartymi na wiedzy na rzecz rozwoju turystyki osób niepełnosprawnych ruchowo w Polsce.

\section{Pojęcie niepelnosprawności}

Światowa Organizacja Zdrowia (WHO - World Health Organisation) i Międzynarodowa Klasyfikacja Funkcjonowania, Niepełnosprawności i Zdrowia (ICF International Classification of Functioning, Disability and Health) wprowadzily następujące pojęcia niepełnosprawności:

- niesprawność (impairment) - to utrata sprawności, nieprawidłowość w budowie i funkcjonowaniu organizmu pod względem psychologicznym, psychofizycznym i anatomicznym;

- niepełnosprawność (disability) - to ograniczenie lub niemożliwość prowadzenia aktywnego życia w sposób i w zakresie uznawanym za typowy dla człowieka;

- ułomność (handicap) - to ograniczenia w pełnieniu funkcji społecznych, ułomność będąca rezultatem niesprawności i niepełnosprawności, ograniczająca pełne spełnianie roli społecznej odpowiedniej do wieku, płci, wykształcenia itp.

Biorąc pod uwagę wyżej wymienione pojęcia, WHO przedłożyło definicję osoby niepełnosprawnej: „Osoba niepełnosprawna to człowiek o naruszonej sprawności funkcjonalnej lub aktywności życiowej w stopniu utrudniającym pełnienie dla 
niej właściwych ról społecznych”. Definicja osoby niepełnosprawnej przyjęta przez WHO obowiązuje na całym świecie. Jednakże termin ten nie jest uniwersalny. W wielu krajach funkcjonuje kilka pojęć niepełnosprawności używanych do różnych celów, np.: rehabilitacji społecznej, zawodowej, opieki zdrowotnej, edukacji itp. (Światowa Organizacja Zdrowia, 2009).

W państwach Unii Europejskiej, a więc również w Polsce, przyjęto jedną, obowiązującą definicję osoby niepełnosprawnej: „Osoba niepełnosprawna jest jednostką w pełni swych praw, znajdującą się w sytuacji upośledzającej ją, stworzonej przez bariery środowiskowe, ekonomiczne i społeczne, których nie może, tak jak inni ludzie, przezwyciężyć wskutek występujących w niej uszkodzeń" (Wapiennik, Piotrowicz 2002, s. 19-21).

W definicji osoby niepełnosprawnej przyjętej przez WHO wyodrębniono trzy aspekty ściśle ze sobą powiązane i decydujące o sytuacji, problemach, potrzebach człowieka niepełnosprawnego, a mianowicie: uszkodzenie (impairment), niepełnosprawność (disability) i upośledzenie (handicap) (Śledzińska, Stasiak 2008, s. 260). Zależność między tymi aspektami zdrowia w ujęciu przyczynowo-skutkowym według WHO przedstawia Rysunek 1.

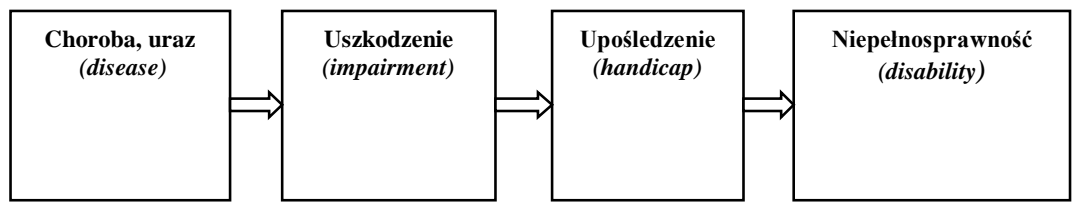

Rysunek 1. Zależność przyczynowo-skutkowa aspektów zdrowia

Źródło: Opracowanie własne na podstawie (Borowicka A. (red.) (2003))

Uszkodzenie pojmowane jako całkowita lub częściowa strata, wada fizjologiczna, psychiczna lub anatomiczna budowy organizmu powoduje choroba, uraz. Uszkodzenie może być nabyte lub wrodzone, ustabilizowane lub progresywne, czyli postępujące w kierunku pogłębiania. Następstwem uszkodzenia jest niepełnosprawność rozumiana jako obniżony poziom czynności danego narządu lub układu organizmu człowieka. Powoduje ona różne ograniczenia funkcjonalne wynikające z uszkodzeń zdolności wykonywania jakiejś czynności w sposób uważany za normalny. Ograniczenia te mają charakter stały lub przejściowy, całkowity lub częściowy i obejmują sferę sensoryczną, fizyczną oraz psychiczną.

Następstwem niepełnosprawności jest upośledzenie, które oznacza utratę możliwości funkcjonowania w życiu społecznym tak jak pozostali obywatele.

Niepełnosprawność to przede wszystkim rezultat barier, z jakimi spotyka się w społeczeństwie osoba niepełnosprawna. $Z$ tego względu niepełnosprawność posiada dwa modele: medyczny (indywidualny) i społeczny.

Medyczny model niepełnosprawności zakłada, że choroby i uszkodzenia organizmu ludzkiego są bezpośrednią przyczyną problemów, na jakie napotykają osoby niepełnosprawne. Traktuje niepełnosprawność jako osobistą tragedię danej osoby. Natomiast w modelu społecznym następuje zmiana w rozumieniu przyczyn niepeł- 
nosprawności - nie szuka się ich w jednostce, lecz w ograniczającym środowisku, barierach społecznych, ekonomicznych i fizycznych. Dyskryminacja to nie problem wynikający z niepełnosprawności, lecz z nastawienia i postaw otoczenia (Gałkowski 2000, s. 167-172).

W Polsce wyodrębnia się także stopnie niepełnosprawności, przyjmując za podstawę sprawność organizmu w zaspokajaniu podstawowych potrzeb życiowych bez pomocy innych osób oraz zdolność do zatrudnienia. Ustawa o rehabilitacji społecznej i zawodowej (Ustawa z dnia 27 sierpnia 1997 r. o rehabilitacji zawodowej i społecznej oraz zatrudnianiu osób niepełnosprawnych) wyróżnia trzy następujące grupy: lekki, umiarkowany i znaczny stopień niepełnosprawności.

\section{Wybrane wyniki badań aktywności turystycznej osób niepelnosprawnych ruchowo}

W artykule przedstawiono wyniki własnych badań przeprowadzonych w środowisku osób niepełnosprawnych ruchowo. Ich celem było poznanie aktywności turystycznej osób $\mathrm{z}$ dysfunkcją narządów ruchu w ciągu ostatnich sześciu miesięcy, jak i ich opinii na temat barier napotykanych podczas wyjazdów turystycznych.

Próbę badawczą stanowiło 112 osób niepełnosprawnych ruchowo. Badanie przeprowadzono w okresie od maja do listopada 2015. Wykorzystanym narzędziem badawczym był kwestionariusz ankiety. Ankiety były rozprowadzane bezpośrednio przez autorkę - wolontariuszkę współpracującą, na co dzień z osobami niepełnosprawnymi. Zastosowano również dobór zwany „kulą śnieżną” - respondenci wskazywali kolejne osoby, które chciałyby wypełnić ankietę. Wśród respondentów znalazła się młodzież i osoby dorosłe, od 16. roku życia posiadające orzeczenie o niepełnosprawności ruchowej. Do badania wybrano następujące stowarzyszenia i szkoły w Polsce:

1. Warmińsko-Mazurski Związek Inwalidów Narządu Ruchu w Olsztynie,

2. Stowarzyszenie Współpracy z Osobami Niepełnosprawnymi „Tacy Sami” w Częstochowie,

3. Zespół Szkół Specjalnych nr 45 w Częstochowie,

4. Stowarzyszenie „Centrum Przedsiębiorczości, Integracji i Edukacji” w Łukowie,

5. Stowarzyszenie Osób Niepełnosprawnych Ruchowo SONAR w Głogowie.

Opracowany kwestionariusz składał się z 25 pytań, z których 20 odnosiło się do analizowanego problemu, a pozostałe to metryczka. W większości pytań zastosowano kafeterię, a niekiedy koniunktywę odpowiedzi. Kwestionariusz nie był zbyt długi, żeby nie zniechęcić badanych do wypełniania go. W ankiecie zawarto pytania odnośnie aktywności turystycznej osób o ograniczonej mobilności, motywacji podejmowanych wyjazdów i zdobywania informacji o możliwościach uczestniczenia w imprezach turystycznych. Ankieta spełniała kryteria anonimowości. 


\section{Analiza przeprowadzonych badań (odpowiedzi respondentów)}

Wśród respondentów było 61 kobiet (54,46\% ankietowanych) i 51 mężczyzn $(45,54 \%$ ankietowanych) $\mathrm{w}$ wieku od 16 . roku życia do ponad 60 lat. Najliczniejszą grupę stanowili badani do 30. roku życia (52 osoby, co daje 46,42\%). W ankiecie najmniejsze grono stanowiły osoby po 56 . roku życia (10 osób, co daje $8,92 \%$ ). Wynika to z łatwiejszego dostępu do grup ludzi młodszych poprzez szkołę, stowarzyszenia, kluby itp.

Istotne dla analizy problemu było uzyskanie danych o stopniu niepełnosprawności ruchowej, wykształceniu i miejscu zamieszkania respondentów.

Wśród respondentów było 68 osób z lekkim stopniem niepełnosprawności ruchowej $(60,71 \%$ ogółu respondentów), natomiast 12 osób posiadało znaczny stopień niepełnosprawności ruchowej, co stanowi 10,71\% ogółu respondentów.

Wśród respondentów było 30 osób z wykształceniem wyższym $(26,78 \%$ ogółu respondentów), 49 osób z wykształceniem średnim (43,75\% ogółu respondentów), 7 osób z podstawowym (6,25\% ogółu respondentów).

Największa część respondentów - 47 osób - zamieszkuje miasta powyżej 100 tysięcy mieszkańców, 9 osób to mieszkańcy wsi, resztę stanowią osoby z mniejszych miast.

$\mathrm{W}$ omawianym rozdziale najbardziej istotne są odpowiedzi dotyczące badanego problemu - aktywności turystycznej. Jedno z pytań dotyczyło aktywności turystycznej w ciągu ostatnich sześciu miesięcy, co przedstawiono na Rysunku 2.

Niepełnosprawni ruchowo najczęściej wybierają podróż dwudniową z jednym noclegiem i to dostarcza wiedzy na temat braku właściwego rozeznania - braku informacji na temat opłacalności wyjazdu. Podróż tygodniowa jest niewiele droższa od wyjazdu dwudniowego, ponieważ najwyższym kosztem obarczony jest transport niepełnosprawnego ruchowo.

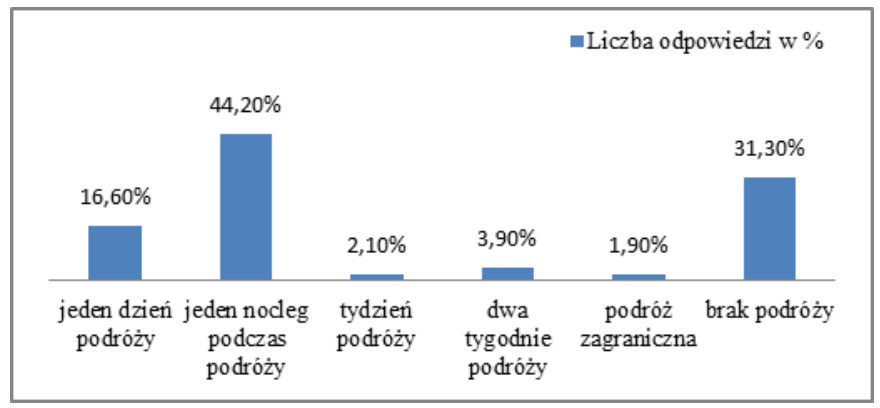

Rysunek 2. Aktywność turystyczna badanych respondentów $(\mathrm{n}=112)$

Źródło: Opracowanie własne

Osoby niepełnosprawne z dysfunkcją ruchu zazwyczaj są zmuszone akceptować poziom dostępności wszystkich usług turystycznych, których głównym mankamentem są bariery finansowe, architektoniczne, urbanistyczne, społeczne, transportowe itp. Jednakże - jak wynika z odpowiedzi ankietowych - brak informacji i wiedzy na temat potrzeb osób $\mathrm{z}$ ograniczoną mobilością jest jedną z najbardziej uciążliwych barier typu organizacyjnego i społecznego - Rysunek 3. 


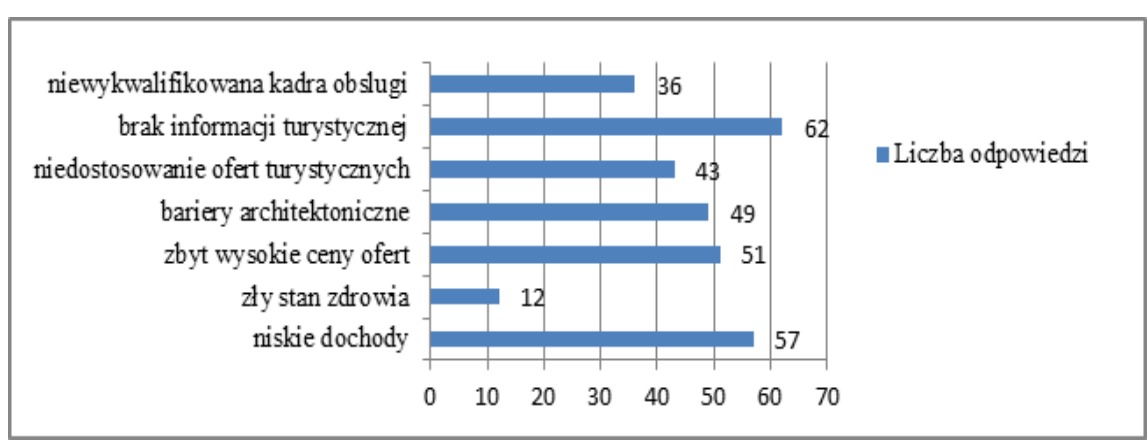

* Możliwość nawet trzech odpowiedzi respondenta

Rysunek 3. Utrudnienia w uprawianiu turystyki przez osoby niepelnosprawne ruchowo $(\mathbf{n}=112)$

Źródło: Opracowanie własne

Ponad 30\% respondentów nie podjęło próby wyjazdu, czego powodem w dużej mierze jest brak informacji o atrakcjach turystycznych dostosowanych do stopnia niepełnosprawności.

\section{Wnioski z przeprowadzonych badań ankietowych}

Należy jak najszybciej tworzyć innowacje usługowe, marketingowe i innowacje w zarządzaniu, ponieważ osób z ograniczoną mobilnością przybywa bardzo szybko. Społeczeństwo polskie zaczyna się starzeć, a co za tym idzie - pojawi się znaczna, dodatkowa grupa niepełnosprawnych ruchowo biologicznie.

$\mathrm{Na}$ rynku turystycznym brakuje odpowiedniego marketingu dotyczącego dostępności różnych produktów turystycznych spełniających wymagania osób niepełnosprawnych ruchowo. Touroperatorzy powinni tworzyć jak najwięcej programów lojalnościowych, które pozwolą zwiększyć sprzedaż produktów i usług turystycznych przy znacznie mniejszych kosztach imprez turystycznych, zwracając także uwagę na promocję i reklamy informujące o możliwościach wyjazdów bez barier architektonicznych, urbanistycznych, finansowych itp.

W celach strategicznych biur podróży należy ująć szkolenia kadry pod względem umiejętności właściwej obsługi klientów niepełnosprawnych ruchowo, którzy wymagają możliwie najpełniejszej informacji o proponowanych usługach. Informacje muszą być podawane w sposób zrozumiały i najlepiej poparte fachową poradą w zakresie wyboru usług turystycznych.

\section{Aktywność turystyczna osób niepełnosprawnych ruchowo w gospodarce turystycznej opartej na wiedzy}

$\mathrm{Na}$ gruncie nowego modelu gospodarki turystycznej opartej na wiedzy klienci niepełnosprawni stają się coraz większą częścią rynku turystycznego tych osób. Poprzez swoje doświadczenia związane $\mathrm{z}$ ograniczoną mobilnością i ważnymi 
uwagami po zakończeniu imprezy turystycznej, dotyczącymi porównania ofert turystycznych ze stanem rzeczywistym, wpływają na modernizację ofert już istniejących. Oddziałując na kształt innowacji usługowych, sami w rezultacie są ich odbiorcami. Rysunek 4 przedstawia proces przenikania wiedzy klienta do przedsiębiorstwa turystycznego, np.: biura podróży, hotele itp.

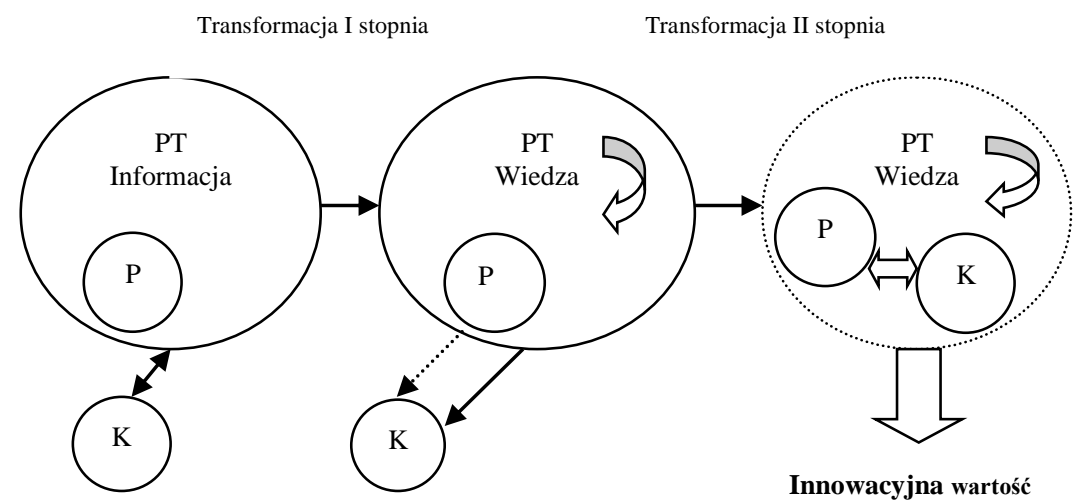

\section{Rysunek 4. Proces przeksztalcania przedsiębiorstwa w innowacyjne przedsiębiorstwo turystyczne oparte na wiedzy}

Źródło: (Januszewska, Nawrocka 2007, s. 6-7)

Objaśnienia:

„Transformacja I stopnia rozumiana jest jako przeksztatcenie polegajace na traktowaniu klienta nie tylko jako źródla informacji o potrzebach i biernego uczestnika transakcji kupna i sprzedaży, ale jako źródta wiedzy przedsiębiorstwa turystycznego. Przedsiębiorstwo powstajace w wyniku tej transformacji to organizacja wykorzystujaca wiedze (ang. Knowledge Intensive Company).

Transformacja II stopnia to przeksztatcenie polegajace na tworzeniu organizacji jako systemu komunikacji, tj. nakładaniu się (przenikaniu do wnętrza) klienta jako obszaru źródtowego i docelowego, a przedsiębiorstwo to takie, które całkowicie się na wiedzy opiera (ang. Knowledge Based Company), inaczej zwane wiedzocentryczne. Linia przerywana oznacza zacierajaca się granicę między organizacja a otoczeniem, szczególnie klientem. Klient dostarcza, a firma pozyskuje wiedze nie tylko dotyczaca satysfakcji, jego potrzeb, ale także wynikajaca z jego doświadczeń życiowych $i$ zawodowych, która pozwala na zastosowanie nowych rozwiqzań $w$ systemie motywacyjnym, procesach technologicznych $i w$ kulturze organizacyjnej.

$K-k$ lient (obszar źródlowy wiedzy),

PT - przedsiębiorstwo turystyczne (obszar docelowy wiedzy),

$P$ - pracownicy przedsiębiorstwa turystycznego,

$\leftrightarrow$ relacje towarowo-pieniężne

$\longrightarrow \rightarrow$ dyfuzja wiedzy,

$\Longleftrightarrow$ socjalizacja, internalizacja wiedzy od klienta (zarządzanie wiedza),

$\rightleftarrows$ spirala wiedzy, która się pomnaża, wzbogaca, tworzy" (Januszewska, Nawrocka 2007, s. 6-7) 
Transformacja II stopnia prowadzi do powstania innowacyjnego przedsiębiorstwa turystycznego opartego na wiedzy, które odznacza się określonymi cechami: zdolnością przewidywania przyszłości, jako umiejętnością pracowników i menedżerów, dialogiem z klientem i jego dostępem do wiedzy firmy, tworzeniem współpracy personelu z klientem, tworzeniem płaszczyzny wymiany doświadczeń, klimatem sprzyjający uczeniu (Mikuła 2006, s. 130-145).

\section{Przegląd dobrych praktyk opartych na wiedzy w rozwoju turystyki osób niepełnosprawnych ruchowo}

Pierwowzorem wszystkich projektów na rzecz dostępności turystyki dla osób niepełnosprawnych jest koncepcja „Turystyka dla wszystkich”, zapoczątkowana w Wielkiej Brytanii w 1989 roku. Ideą tej koncepcji jest umożliwienie korzystania z usług turystycznych wszystkim ludziom, niezależnie od ich niepełnosprawności, ograniczeń zdrowotnych czy finansowych. Zrzeszając organizacje branżowe, agencje rządowe, instytucje pozarządowe i lokalne, „Turystyka dla wszystkich” realizuje projekty mające na celu poprawę sytuacji tej grupy społecznej. Wspólnym mianownikiem tych działań jest ułatwienie niepełnosprawnym pełnego uczestnictwa we wszystkich przejawach życia społecznego, w tym w turystyce (Grabowski 2008, s. 55).

Wiele innych organizacji i instytucji podejmuje działania na rzecz poprawy turystyki osób niepełnosprawnych ruchowo. Mają one różne założenia i charakter, ale głównym ich celem jest szkolenie kadry branży turystycznej, która w sposób profesjonalny będzie obsługiwała klientów niepełnosprawnych. Do projektów o zasięgu ogólnoświatowym zalicza się (Grabowski, Milewska, Stasiak 2007, s. 51-52):

- ENAT (European Network for Accessible Tourism) - promuje i dba o rozwój ośrodków turystycznych, produktów i usług, dostępnych dla turystów w każdym wieku i z różnymi niepełnosprawnościami.

- OSSATE (One-Stop-Shop for Accessible Tourism in Europe) - kompleksowa obsługa turystyki w Europie, promuje produkcję, dystrybucję i użytkowanie cyfrowych usług informacyjnych.

- EU.FOR.ME (Tourist Training for a Wider Target) - szkolenia z turystyki dla szerszej grupy docelowej; podstawowym celem jest identyfikacja potrzeb i wymogów osób niepełnosprawnych w zakresie ich udziałów w turystyce i na tej podstawie stwarzanie systemu szkoleniowego dotyczącego zagadnień związanych z dostosowaniem usług obiektów do ich potrzeb.

- GASTFREUNDSCHAFT FUR ALLE (Gościnność dla wszystkich) - obejmuje realizowany w regionach turystycznych Niemiec system szkoleń dla przedstawicieli branży hotelarskiej i gastronomicznej mający na celu tworzenie i wprowadzanie na rynek produktów i usług przystosowanych do wymogów osób niepełnosprawnych.

- DIADA (Opracowanie $i$ wdrożenie nowych metod szkoleniowych $w$ sektorze turystycznym) - głównym celem było stworzenie oraz wdrożenie nowego systemu szkoleniowego dla całego europejskiego przemysłu turystycznego przy równoczesnym zaangażowaniu osób niepełnosprawnych. 


\title{
Przykłady projektów i przedsięwzięć w Polsce opartych na wiedzy na rzecz rozwoju turystyki osób niepełnosprawnych ruchowo
}

\author{
(Popiel 2013, s. 130-131)
}

Po wejściu Polski do Unii Europejskiej coraz większy nacisk kładzie się na rozwój turystyki dla wszystkich, w tym dla osób niepełnosprawnych z dysfunkcją ruchu. Efektem są różne innowacje o zasięgu lokalnym lub krajowym bazujące na wiedzy.

W ramach otwarcia na potrzeby osób niepełnosprawnych powstał projekt „Polska bez barier”. Jego głównym celem jest poprawa dostępności polskich miast dla osób niepełnosprawnych ruchowo poprzez dostosowanie obiektów użyteczności publicznej do ich potrzeb.

Następnym przedsięwzięciem jest otwarcie biura turystycznego Accessible Poland (2008 r.), które prowadzone jest przez osobę niepełnosprawną od urodzenia. To innowacyjne biuro turystyczne, którego działalność oparta jest na procesie osobistej wiedzy założycielki, nastawione jest na kompleksową obsługę osób niepełnosprawnych ruchowo.

Dofinansowany w ramach Małopolskiego Regionalnego Programu Operacyjnego, a realizowany przez Urząd Miasta Krakowa, projekt: „Droga Królewska dla niepełnosprawnego turysty" przyczynia się do rozwoju nowego segmentu turystyki kwalifikowanej. Głównym założeniem projektu jest udostępnienie turystom niepełnosprawnym dziedzictwa kulturowego Krakowa poprzez stworzenie atrakcyjnej, pozbawionej barier architektonicznych trasy turystycznej.

\section{Podsumowanie}

Społeczeństwa w gospodarce opartej na wiedzy coraz częściej stają się świadome potrzeb osób niepełnosprawnych ruchowo, które odczuwają chęć podróżowania.

Dostępność „turystyki dla wszystkich” stanowi integralną część gospodarki, w której jednym z ważnych celów jest udostępnienie turystyki dla jak największej potencjalnej liczby turystów niepełnosprawnych. Ważnym wymogiem jest dostarczenie informacji, której efektywne przekształcenie w wiedzę najczęściej skutkuje innowacyjnymi rozwiązaniami. Powstaje szereg projektów o zasięgu międzynarodowym i krajowym, dzięki którym udostępnienie usług, produktów, obiektów na potrzeby osób niepełnosprawnych niesie korzyść dla samych zainteresowanych, jak i dla przedsiębiorstw turystycznych.

Touroperatorzy i pośrednicy turystyczni już w planie strategicznym powinni ująć problem dotarcia $\mathrm{z}$ informacją turystyczną do potencjalnego klienta niepełnosprawnego i za jeden z głównych celów postawić wykształcenie kadry agencji turystycznej pod kątem bezpośredniego obcowania $\mathrm{z}$ osobami niepełnosprawnymi ruchowo. Rolą detalicznego agenta podróży jest przedstawienie ofert i zorganizowanych pakietów usług przyszłemu turyście niepełnosprawnemu i poinformowanie go o tych usługach turystycznych w sposób szczegółowy i zrozumiały. 
Wspomniane w artykule wybrane, pozytywne praktyki na rzecz rozwoju aktywności turystyki osób niepełnosprawnych ruchowo są doskonałą inspiracją do przyszłych, lepszych przedsięwzięć mających na celu pomoc w udostępnieniu „turystyki dla wszystkich".

\section{Literatura}

1. Borowicka A. (red.) (2003), Niepetnosprawny turysta. Poradnika dla pilotów i przewodników turystycznych, Forum Turystyki Pomorza Zachodniego, Szczecin.

2. Gałkowski T. (2000), Nowe podejście do niepetnosprawności. Uporządkowanie terminologiczne, Polskie Towarzystwo Niepełnosprawnych Zarząd Główny, Lublin.

3. Grabowski J. (2008), Projekty na rzecz rozwoju turystyki osób niepetnosprawnych, [w:] A. Stasiak (red.), Rola krajoznawstwa i turystyki w życiu osób niepetnosprawnych, PTTK „Kraj”, Warszawa.

4. Grabowski J., Milewska M., Stasiak A. (2007), Vademecum organizatora turystyki niepetnosprawnych, WSTH w Łodzi, Łódź.

5. Jankowska J. (2011, 2012), Prawa osób niepetnosprawnych $w$ międzynarodowych aktach prawnych, „Niepełnosprawność. Kwartalnik”, nr I/2011(1), II/2012(2), Warszawa.

6. Januszewska M., Nawrocka E. (2010), Innowacyjne przedsiębiorstwo turystyczne oparte na wiedzy, [w:] K. Rogoziński, A. Panasiuk (red.), Zarzadzanie organizacjami ustugowymi, „Zeszyty Naukowe Uniwersytetu Ekonomicznego w Poznaniu”, nr 145, Wydawnictwo Uniwersytetu Ekonomicznego w Poznaniu, Poznań.

7. Kaganek K. (2009), Turystyka osób niepetnosprawnych $w$ aspekcie wybranych uwarunkowań, EAS, Kraków.

8. Mikuła B. (2006), Organizacje oparte na wiedzy, Wydawnictwo Akademii Ekonomicznej w Krakowie, Kraków.

9. Popiel M. (2013), Accessible Tourism In a Knowledge-based Economy, Uniwersytet Jagielloński w Krakowie, Kraków.

10. Skalska T. (2010), Nowe wyzwania gospodarki turystycznej. Turystyka osób niepetnosprawnych: Porady dla ustugodawców, Szkoła Wyższa Przymierza Rodzin, Warszawa.

11. Śledzińska J., Stasiak A. (2008), Rola krajoznawstwa i turystyki w życiu osób niepetnosprawnych, PTTK „Kraj”, Warszawa.

12. Światowa Organizacja Zdrowia (2009), Międzynarodowa Klasyfikacja Funkcjonowania, Niepetnosprawności $i$ Zdrowia, Centrum Systemów Informacyjnych Ochrony Zdrowia, Warszawa.

13. Ustawa z dnia 27 sierpnia 1997 r. o rehabilitacji zawodowej i społecznej oraz zatrudnianiu osób niepełnosprawnych (Dz.U. $1997 \mathrm{nr} 123$ poz. 776, z późn. zm.).

14. Wapiennik E., Piotrowicz R. (2002), Niepetnosprawny - petnoprawny obywatel Europy, Urząd Komitetu Integracji Europejskiej, Warszawa. 


\title{
THE INFLUENCE OF LACK OF KNOWLEDGE AND INFORMATION IN PHYSICALLY DISABLED PEOPLE TOURISM
}

\begin{abstract}
Currently, the tourism industry is one of the most dynamically developing sectors of the world economy. From year to year the number of tourists is increasing and touristic travels are considered as one of important component of people's lives. However, despite the still ongoing development -the disabled people tourism is still rare occurrence. This is mainly due to the lack of knowledge about the market of tourists with special needs, marketing, customization, spatial infrastructure and tourist business management based on the dialogue with disabled customers. The article includes examples of innovative projects for disabled people tourism development, introduces the concept of disability and presents an analysis and the own research results concerning disabled people tourist activity.
\end{abstract}

Keywords: innovation, management, marketing, physically disabled people tourism, tourist services, tourism, tourism economy based on knowledge 